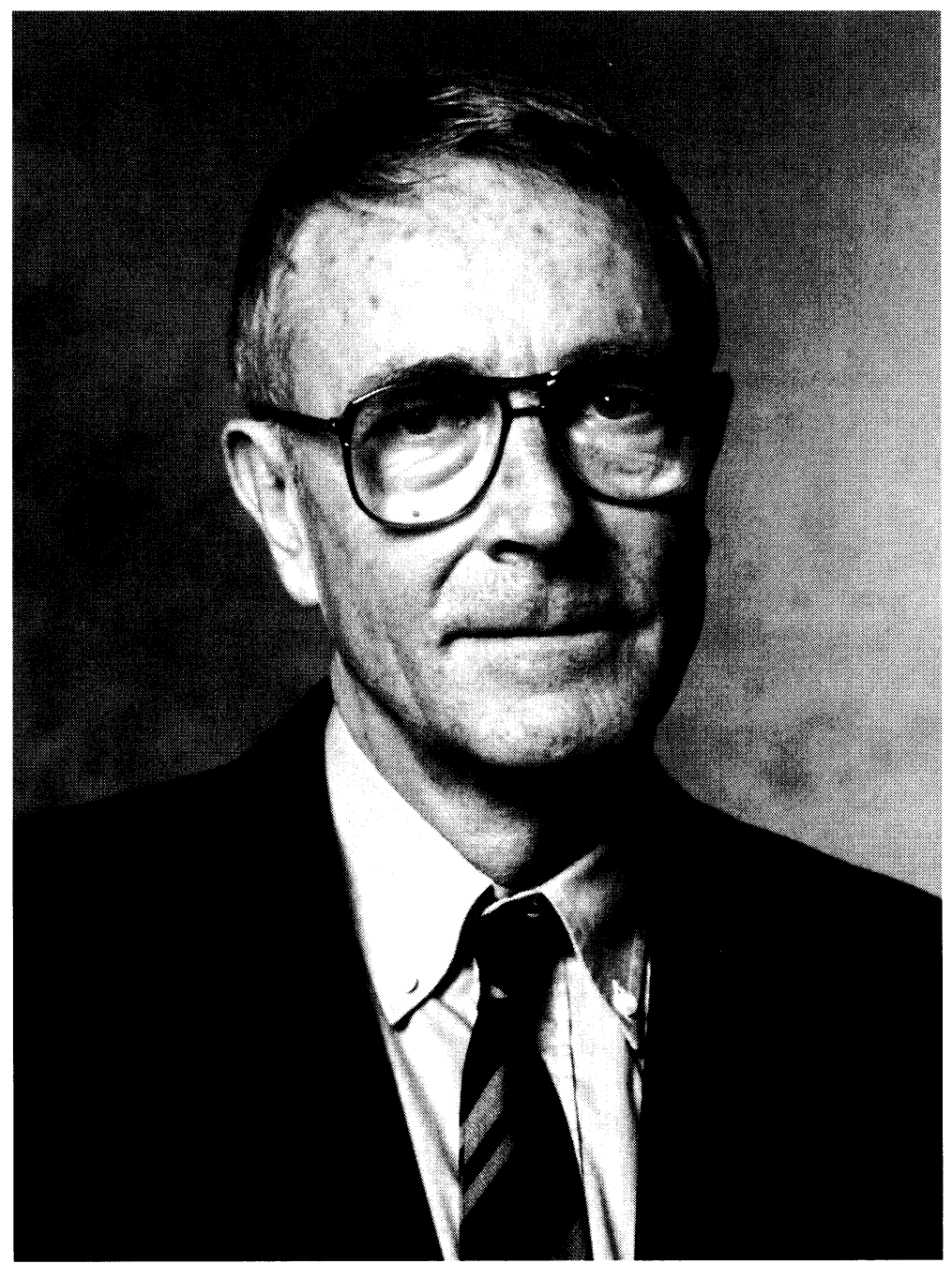

Foto: Rigmor Mydtskov

Jakob Leth Balling

11. februar 1928 - 13. januar 2012 


\title{
Jakob Balling in memoriam
}

\author{
Af Søren Jensen
}

Med Jakob Ballings død i januar 2012 har dansk kirkehistorie mistet en af sine fremmeste og mest kyndige repræsentanter. Fra sin ansættelse som professor ved Det teologiske Fakultet på Aarhus Universitet $\mathrm{i}$ 1964 med oldtid og middelalder som sit område til sin pensionering $\mathrm{i}$ 1998 satte Jakob Balling en standard ikke blot for faget, men også for undervisningen i faget. Det var ham magtpåliggende at understrege, at kirkehistorie er en teologisk disciplin. Balling yndede at tale om sit fag som kristendomshistorie, hvormed det kristne budskabs rolle åbnede for en mere facetteret faglig praksis og dermed for en større nytteværdi for dem, der har med de øvrige teologiske fag at gøre, og i særdeleshed for de studerende.

Med den periode af kirkehistorien, som var Ballings, syntes det ikke specielt oplagt, at han skulle fatte interesse for Grundtvig. Men hans periodiseringskritik viste sig også $\mathrm{i}$ hans irritation over, at man som kirkehistoriker kun kunne beskæftige sig med eller udtale sig om emner, der vedrørte 'ens egen periode'. Bortset fra det havde han stor respekt for ekspertise. I sin anmeldelse af Grundtvig og grundtvigianismen $i$ nyt lys (1983) hilser Balling denne publikation velkommen "for alle, der - som anmelderen - ikke selv er specialist på feltet". Han kunne ellers nok have kaldt sig specialist også på dette felt i lige så høj grad som så mange andre.

I sin bog Kristendommen (1986) gav Balling et samlet bud på hele kirkens historie og disponerede den netop i overensstemmelse med sin egen periodiseringspraksis på følgende måde: Kristendommens tilblivelse, Kristendommen som Middelhavsreligion (100-750), Gammeleuropæisk kristendom (750-1800) og Nyeuropæisk kristendom (1800 ff.). Ud over at rumme et opgør med den traditionelle periodisering fremhæver denne disponering kristendomshistoriske traditionslinjer, som man ellers ikke så tydeligt får øje på.

Et sted, hvor Balling havde sit kristendomshistoriske fokus rettet hen, var mod de store episke digtere Dante og Milton og deres muligheder for at optræde som teologer. Om Divina Commedia og Paradise Lost udgav han en sammenlignende studie i 1983, som han kaldte Poeterne som kirkelcerere, hvori han tydeliggjorde både traditionssammenhænge, ligheder og forskelle og afdækkede samspillet mellem poesi og forkyndelse. Forholdet mellem teologi og litteratur havde Balling på dette tidspunkt beskæftiget sig med i mange år. Baggrunden skal fin- 
des i den interesse for poesi, som blev grundlagt i hans skoletid og som medvirkede til, at han valgte litteraturstudiet hos Paul V. Rubow, da han begyndte at studere. Efter skiftet til teologi slap interessen for poesien ham imidlertid aldrig. I tiden umiddelbart før sin død arbejdede Balling på et projekt, der bl.a. omfattede Alfred Tennyson.

Det er ikke utænkeligt, at det var betydningen af Vergils Eneide i den vesteuropæiske dannelseskultur, altså samspillet mellem poesi og aktuel virkelighed, der åbnede hans øjne for den ejendommelige blanding af teologi og poetisk metode, han studerede hos Dante og Milton. Under alle omstændigheder var det fra disse digtere, han kom, da han ved Kirkeligt Samfunds seminar om Nyaars-Morgen på Båring Højskole i maj 1983 holdt et foredrag om "Nyaars-Morgen som teologisk poesi". Desværre blev seminaret ikke fulgt op af en samlet udgivelse, hvilket ellers havde været oplagt. Balling berørte igen Nyaars-Morgen ved et symposium i 1985 om menneskesynet i senantikken i et bidrag, han kaldte "Et 'augustinsk' tema i europæisk poesi". Temaet var spørgsmålet om, hvordan man erhverver sig identitet. At NyaarsMorgen kan bidrage til at besvare dette spørgsmål, antydes allerede i den karakteristik, som Balling gav digtet: "en slags selvbiografisk meditation, nærmere betegnet et forsøg på mytisk tolkning af digterens levnedsløb" (Historisk Kristendom, 2003, 92). Her omtales altså den identitetserhvervelse, der redegøres mere detaljeret for i "Grundtvig, Dante, Milton, and the Problem of European Continuity" (Heritage and Prophecy, 1993), en artikel, der kom på dansk i en "let varieret" udgave, "Tradition og modernitet i "Nyaars-Morgen"” i Dansk teologisk Tidsskrift (1998).

I bogen om Dantes og Miltons store digte havde Balling interesseret sig for traditionssammenhænge og den omformning, som var sket med traditionen hos Milton i relation til hans tid og omgivelser, altså forholdet mellem tradition og modernitet hos Milton. I mindre format gjorde han noget lignende i artiklen om Nyaars-Morgen, og spurgte, om der i dette digt, som blev til efter et periodeskel, Balling selv plæderede for, kunne påvises en traditionssammenhæng, og hvorledes den i givet fald omformedes af den 'modernitet', som hørte Grundtvigs tid og sted til.

Traditionssammenhængen hos de klassiske gammeleuropæiske digtere karakteriserede Balling ved digter-jegets profetiske status, ved spørgsmålet om, hvad der konstituerer sammenhængen i historie og i verden, ved digtets karakter af moderniseret helligskrift, ved det poetiske univers med én person som midtpunkt for erkendelsen af alt dette og endelig ved den appel, som digtene rummede ved at gengive en konsistent orden til antagelse for hovedpersonen og derfor også for digteren og læseren. 
De gennemgående træk i Nyaars-Morgen, hvor vi har at gøre med en vision af personlig skæbne og kald, giver sig for Balling til kende gennem forståelsen af, hvad kristendom vil sige, hvad historiens sammenhæng går ud på, og hvad et folk er, samt i de formale og materiale relationer, hvori denne vision står til fundamentale strukturer og tendenser hos Dante og Milton.

Både Dante og Grundtvig kæmper med deres identitet og med meningen i det fortidige og det nutidige liv. Balling skildrer, hvorledes de begge går bag facaden - bogstaveligt talt - og under jorden sammen med en vejviser for at finde en forklaring. Og bevægelsen fortsætter herfra tilbage til liv og lys, men med den forskel, at hvor Dante finder sig selv og fornyes i relation til en omverden, fremstår Grundtvig som den ensomme romantiker. I lille format afspejler det bruddet i europæisk åndsliv. Udkæmpelsen af denne kamp er ikke alene en individuel sag, men er vigtig for alle andre, for denne kamp har en parallel i Jesu historie.

Grundtvig benyttede sig af poetiske virkemidler, som vi både kender fra Dante og Milton: fortsættelsen og udfyldningen af den hellige historie, f.eks. når han forstår Danmark som historiens Palæstina, eller når sammenvævningen af bibel- og danmarkshistorien forbindes med læren om de første og de sidste ting. Samarbejdet mellem teologi og poesi i Nyaars-Morgen gør det derfor berettiget at se Grundtvig i traditionen efter Dante og Milton, men Balling understreger samtidig, at han står i traditionen på sin egen måde. Således spiller historien som nordisk national historie en større rolle, end den bibelske i og for sig gør det, og den kosmiske orden eller verdensbilledet, som har stor betydning for opbygningen af de klassiske digte, er nærmest fraværende i Nyaars-Morgen. Både landskab og natur er til stede, men i symbolsk forstand, typisk for det romantiske digt, der er tale om.

Med sin poetiske erfaring gav Balling her en nøgle til at åbne et meget vanskeligt digt med, så man - ikke mindst som nutidig læser får blik for erkendelser i digtet, som man ellers ikke nødvendigvis noterer sig.

Som led i forskeruddannelsen ved det daværende Institut for Kirkehistorie blev der oprettet en studiekreds, der arbejdede med kirkehistoriografi og som sit sidste projekt satte sig for at efterspore en grundtvigsk tradition $\mathrm{i}$ dansk kirkehistorieskrivning. Det kunne der være grund til, fordi de første grundtvigianere, der blev ansat på Det teologiske Fakultet, var kirkehistorikere, men derudover også, fordi inspirationen fra Grundtvig gav sig til kende i historiske forfatterskaber uden for universitetet. Da idéen blev forelagt gruppen, var Ballings støtte afgørende for, at dette projekt blev valgt. Med til planen hørte det, at arbejdet skulle munde ud i en udgivelse, og det skete i 1994 med Kirken af 
levende Stene. Heri skrev Balling (foruden de "Afsluttende bemærkninger" til hele bogen) om den ældre Grundtvig som kirkehistoriker: "Bispestav, skolemesterpen - og menighed".

'Den ældre Grundtvig' vil først og fremmest sige forfatteren til Kirke-Speil, men for at belyse forholdet mellem historie og kirkehistorie hos Grundtvig inddrog Balling også Haandbog $i$ Verdens-Historien. Ganske vist understregede Grundtvig her, at han skelnede skarpt mellem "Kirke og Skole, Tro og Vidskab", men Balling måtte ikke desto mindre konkludere, at hans universalhistoriske praksis var kristendomshistorisk. Det hænger sammen med en af Grundtvigs præmisser, at al slags historie er menneskehistorie, $\mathrm{g}$ at den handler om menneskets successive udvikling til selvbevidsthed. Den hellige historie kan altså dybest set ikke skilles fra den universelle. I Kirke-Speil hedder det, at "Herrens og hans Menigheds Maal er det samme som Menneske-Slægtens, den Menneske-Slægt der er sig selv levende bevidst" (Historisk Kristendom, 253). Menneskelivets oplysning, forklarelse og forevigelse er såvel menneskeslægtens som menighedens mål. Kristenfolket er som et virkeligt menneskefolk underlagt de vilkår, der hører til det at være et folk. Derfor tager kristendommen nødvendigvis skikkelse på en bestemt folkeligheds betingelser og kan ses udbrede sig gennem disse forskellige folk.

I Kirke-Speil tager Grundtvig afsæt i sin egen erfaring, dvs. i "den mageløse opdagelse", og som endnu en præmis for det kirkehistoriske arbejde opspores hermed den frie menigheds kendelige liv, hvormed Grundtvig afgjorde, hvad der hører med til kirkehistorien, og hvad der ikke gør. Derved toner et noget andet billede end det gængse frem, hvori Balling finder "momenter af trivialitet, og af doktrinær monotoni", men rigtignok også "træk af bemærkelsesværdig friskhed og tankevækkende perspektiver" (Historisk Kristendom, 255). At den græske kirkes brug af Nicænum ved dåben udelukker den fra kirkehistorien, hører til den doktrinære monotoni.

Det er det kendelige trosord i menigheden, der er afgørende, så hvor teologerne ("Skolemester-Pennen") eller hvor kleresiet ("BispeStaven") tiltager sig autoritet, forvanskes kirken. Disse præmisser gør det muligt for Grundtvig at manøvrere i det store stof. Det betyder netop, at meget betragtes med friske øjne, f.eks. Luther og reformationen. Luther gjorde både op med boglighed og bispelighed, men han manglede sans for menigheden som et kendeligt folk. Reformationen var nok et opgør med pavetyranni og anden ukristelighed, men efter Luther udviklede den sig til skolemestertyranni.

Balling sluttede med at opregne de fortrin og svagheder, der er ved Grundtvigs arbejdsmetode. Der åbner sig mange nyttige perspektiver ved at begynde med menigheden som et definerbart, kendeligt samfund 
$i$ en bestemt folkelig sammenhæng, ligesom den teologisk begrundede præmis giver Grundtvig et mere sikkert grundlag at bedømme tingene på. Men den benhårde doktrinarisme, hvormed Grundtvig bruger sin anskuelse, har indimellem urimelige konsekvenser. Det er sådan set påfaldende, hvor abstrakt Grundtvig tænker, hvilket sikkert hænger sammen med hans hang til spekulation, siger Balling (Historisk Kristendom, 262), og endelig mener han, at Grundtvigs kompromisløse vilje til at beskrive historien som en planmæssig progression drives for vidt.

Spørgsmålet om en grundtvigsk tradition i dansk kirkehistorieskrivning besvarer Balling bekræftende, men det var tradition i betydningen "fælles inspiration gennem flere generationer fra Grundtvigs måde at omgås kirkehistorien på" (Kirken af levende Stene, 228). De grundtvigske kirkehistorikere var også inspireret andre steder fra, for det er et kendetegn ved 'traditionen', "at det traderede indføjes i nye kombinationer". Alligevel må man spørge, om Grundtvigs indsats som kirkehistoriker i grunden var så markant, at han kan kaldes ophavsmand til en egentlig tradition. "Kristne fortidsmennesker eller fortidsmenigheder som vælgende og handlende under deres tiders og deres steders vilkår og begrænsninger interesserer ham ikke, eller ikke så meget, at han har fundet det nødvendigt at lade det komme til udtryk i sin kirkehistorieskrivning". Balling gør opmærksom på, at "den kristne jegperson N. F. S. Grundtvig selv, hvis livsoplevelser det samlede kirkehistorieforløb spidser til i og udmunder i" (Kirken af levende Stene, 229), repræsenterer en undtagelse fra denne regel. At Grundtvig betragtede sig selv på denne måde, nævner Balling et andet sted og skriver, at selvom det ved første blik ser egocentrisk eller ligefrem "storhedsvanvittigt" ud, hvortil føjes: "der er formodentlig virkelig et element af det tilstede" ("Indledningsbidrag til seminar om "Grundtvig og den tidlige tradition"”, 1995, 2), er der grund til at nævne, at der er tale om en gammeleuropæisk tradition: at forstå sig selv i meningsfuld forbindelse med historien, sådan som man også kan se det hos Dante og Milton.

Grundtvig arbejdede med spørgsmålet om, hvad kirkehistoriens genstand var og ikke var, med frafaldet fra sand kristendom, med forholdet til de forskellige folkeligheder, med menneskeåndens bevidstgørelse, med analogier mellem enkeltpersoners og slægtens udvikling, altså i og for sig generelle synspunkter på, hvad kirkehistorisk arbejde går ud på. Det kunne gøre Grundtvig til inspirator, men kunne ikke i egentlig forstand gøre ham til lærer.

Balling ærgrede sig lidt over, at Grundtvig ikke i højere grad havde inspireret generationerne efter ham til at stille nye spørgsmål til gammelkendt stof, for (som han skrev i en rapport fra et grundtvigseminar i Chicago i 1995) “værdifulde impulser kan vindes ved at gå til Grundt- 
vig 'udefra'" (Grundtvig-Studier 1996, 152). Det var en metode, Balling i høj grad sympatiserede med, og som han selv benyttede. Gang på gang tog han de samme tekster frem, stillede dem nye spørgsmål og aftvang dem nye svar. Det făr man klart indtryk af, hvis man læser hans artikler og afhandlinger, som kom i Historisk Kristendom (2003), og hvori det meste af, hvad han har skrevet om Grundtvig, er at finde.

Der er ingen tvivl om, at Balling selv følte sig inspireret af Grundtvig. Når han i slutningen af en forelæsning om kristen humanisme sagde, at han ikke ville komme ind på Grundtvig, at denne ikke får ordet, og tilføjer: "i hvert fald ikke udtrykkeligt", så betyder det, at Balling betragtede Grundtvig som en åndsfælle. Det betød netop ikke, at Balling ikke kunne være kritisk over for Grundtvig, men han optrådte som hans indforståede, 'solidariske' kritiker.

Balling betragtede Grundtvig som poet overalt $i$ hans værk, og det var især digteren, der havde hans interesse. Han har skrevet både om salmerne og sangene, og han værdsatte i høj grad Grundtvigs digteriske evner. Om Nyaars-Morgen skriver han et sted, at dette digt indeholder "nogle af de bedste vers, der er skrevet på dansk" (Historisk Kristendom, 93). Men han lagde ikke skjul på, at han mente, at "Grundtvig har ladet adskilligt trykke, som et beskedent mål af den selvkritik, prosaiske medborgere opdrages til, ville have foranlediget ham til at lade gå lukt i kakkelovnen" (ibid. 275). Udtalelsen tyder på at være fremsat, umiddelbart efter at Balling havde læst Sang-Vark uafbrudt fra ende til anden.

Et arbejde, Balling påtog sig efter at være blevet pensioneret, var at oversætte A.M. Allchins N.F.S. Grundtvig. An Introduction to his Life and Work (1997) til dansk. Bogen var skrevet til et engelsktalende og engelsktænkende publikum, og den fremmede vinkel med vægten lagt på det økumeniske og på gudstjenesten som stedet, hvor historien indoptages og opfyldes, ansporede Balling til at gå i gang med dette arbejde. Det var krævende, men Balling gik op i det med stor iver. Han gjorde meget ud af at verificere citater og faktuelle oplysninger, hvilket ikke altid var lige nemt. Som den sprogets - eller sprogenes - mester, han var, befandt han sig godt med at oversætte, og i 2002 udkom bogen med titlen Grundtvigs kristendom. Menneskeliv og gudstjeneste.

Jakob Balling får det sidste ord med et citat fra det sted i bogen Kristendommen, hvor han nævner Grundtvig, fordi det åbner perspektivet fremad: "Den danske betragter af nyeuropæisk kristen tænkning gør vel i at afslutte betragtningen med et blik på en dansk tænker, der ikke lader sig rubricere: Grundtvig. Ikke fordi han 'løser' noget problem, andre har måttet lade uløst, så meget mindre som han døde før modernitetens problemer antog deres fulde skarphed. Men fordi det gamle Europa og det nye, traditionen og samtiden, hos ham lever 
sammen i en tæthed der savner sidestykke, og som har en del at gøre med, at hans formuleringsmiddel - uanset om han skriver vers eller prosa - er poesien. Når Grundtvig på én gang tænker 'katolsk' og 'demokratisk' om kirken, og når han om mennesket og dets muligheder ikke bare tænker 'luthersk', men også 'humanistisk', så ligger et af udspringspunkterne derfor i den evne til billedlig sammenfatning og sammenskuen, som han har tilfælles med sine forgængere, de gammeleuropæiske teologiske poeter. Det er ikke tilfældigt, at tankebaner, som betrådtes af Dante og Milton, genfindes i Grundtvigs værker, tydeligst i 'Nyaars-Morgen' fra 1824. Og det kan være, at denne måde at drive teologi på også er en med fremtid $i$, hvis den falder i de rette hænder" (276 f.). 